and the 'grey' lists of the treaty on land-based sources of pollution - not just to assess their sources, levels of pollution, and effects on people and marine life, but to propose concrete measures to do something about them. We are no longer merely furnishing facts. The substances I am talking about include, among many others, used motor oil, mercury, cadmium, radioactive ones, pesticides and other organic pollutants on the 'black' list and, on the 'grey' list, lead, zinc, tin, chromium, silver, crude oil, detergents, and pathogenic microorganisms.'

\section{Shipping Industry Involvement}

The European Community has been a very active participant in the Mediterranean Action Plan. Recently it sponsored a workshop on the shipping industry and the marine environment, in Athens, that was organized by the Hellenic Marine Environment Protection Association (HELMEPA). 'When we set out to interest shipowners, captains, and crews, in protecting the sea from pollution, I was very sceptical', admitted Dimitris Mitsatsos, Director-General of HELMEPA. 'Well, in only four years we have enlisted 400 ships, over 3,000 officers and sailors, and most Greek shipowners. We have succeeded in very slowly changing the mentality of thousands of seafarers, and in getting through to their consciences. It is a measure of our success that the Athens workshop [in June 1986], under EEC auspices and with the participation of Beate Weber, the chairwoman of the Environmental Committee of the European Parliament, urged 'the general adoption and extension of HELMEPA's approach to merchant marines on a worldwide basis'.'

The Director of UNEP's MAP, Aldo Manos, mentioned, as another indication of Mediterranean governments' seriousness, the ratification by Greece on 20 June of the treaty on Specially Protected Areas. This brought the number of ratifying countries to six plus the European Community, as a result of which the treaty will enter into force very shortly.

PAUL Evan RESS
Regional Office for Europe
United Nations Environment Programme
Avenue Trembley 16
Petit-Saconnex
Geneva, Switzerland.
Regional Office for Europe United Nations Environment Programme Petit-Saconnex Geneva, Switzerland.

\title{
Environmental Bankruptcy in Haiti
}

Christopher Columbus described Haiti as 'Filled with trees of a thousand kinds and tall'. But no longer is it so; indeed, if present trends continue, this small Caribbean island nation on the doorstep of the USA could be completely deforested within fifteen years.

Haiti is experiencing an environmental crisis as severe as are those of the African countries bordering the Sahara. Five years ago, FAO estimated that Haiti was losing the fertility of 6,000 hectares (ca 15,000 acres) of land each year. The rivers and streams are choked with mud, and far out to sea beyond the capital, Port au Prince, the water is stained brown with mud. Rapid population growth, hurricanes, and frequent droughts and flooding, have all contributed to the crisis, but the real blame lies with decades of neglect under the regimes of the Duvaliers, both father and son.

Evidence of that mismanagement is seen on the border with the Dominican Republic, where, on the Dominican side, there is thick forest, whereas on the other side the hillsides are bare. Neglect of investment in agriculture, forestry, and sources of energy, has left the vast majority of Haitians with no alternative other than to fell the trees and over-use the land. Haiti is one of the few countries where agricultural productivity is actually declining.

With fertile land becoming increasingly scarce, more and more villagers are turning to firewood collection. Virtually all the trees around the capital have been cleared, and the only significant stands left are in the remoter areas in the northern part of the island; but now these, too, are rapidly being felled. According to a World Bank Survey, the current 2.4 million cubic metres' deficit of firewood is destined nearly to treble by the turn of the century.
There are few energy alternatives. An American-built hydroelectric dam at Peligre in the mountains near the Dominican border is clogged with silt and operating at only one-quarter of its intended capacity. A recent expert survey concluded that it may have to shut down if siltation is not stopped.

Many villagers have no alternative other than to leave the land-the drift to the slums of Port au Prince has become a torrent. Virtually everyone you talk to in the slums is a recent arrival, their dream being to escape to the United States. The US Coastguard now keeps a permanent flotilla off Haiti, to intercept illegal immigrants who are prepared to make the risky crossing to Florida.

A massive relief effort is needed to help the post-Duvalier Government to begin the work of rehabilitation - by no means a hopeless task, as for example under a US AID $\$ 8$ million scheme, volunteer groups have encouraged villag. ers to plant 17 million trees in the past four years. Of those trees about $20 \%$ survive, which is a very respectable rate. But it is going to take more than tree-planting to rescue Haiti from such a long-term decline. According to UNICEF, $73 \%$ of all Haitian children of school age are suffering from some form of malnutrition. Sooner rather than later, the new Government will have to turn far more of its attention than currently to improving the lot of the vast majority of Haiti's poor, who must live with the day-to-day realities of environmental bankruptcy.

\author{
RoBert P. LAMB, Director \\ TVE Television Trust for the Environment \\ 46 Charlotte Street \\ London WIP ILX \\ England, UK.
}

\section{New Northern Look}

The Arctic Institute of North America, now of the University of Calgary, is updating its newsletter Information North, which it has published over the years as an informal vehicle for keeping its subscribers informed. In the past, such newsletters tended to focus on membership matters, and accordingly to be cast in a chatty framework with sto- 
ries on good old Harry Smith going back to the Arctic for another summer of watching the bugs and the beetles.

But the North is much more sophisticated in the late nineteen-eighties than formerly, and most of the subscribers do not know Harry Smith and are not all that interested in bugs and beetles any more. Rather do they care to view the broader scene. For instance, how is political devolution getting along in the NWT? What is the future of the mineral industry? Is the anti-fur-harvesting lobby having an effect? What is the view of northerners on the DEWLine rebuilding? What is the fundamental basis for subdivision of the Northwest Territories? Is the proposal to build a class-eight icebreaker solely a question of Canadian sovereignty or is it tied into the so-called 'Star Wars' scenario? What is the next boom-and-bust cycle going to be based upon? Will the languages of the majority (the native peoples) and the government of the majority in the north of Canada lead to a nation of the majority?

Information North is aware of these and other large questions, and has taken steps to change its editorial format to address them. Without adopting any sort of advocacy stance, Information North feels a responsibility to present essay treatments of such topics. Thus, entire issues are devoted to single topics, apart from retaining a few "departmental' items such as up-coming northern conferences. For example, Information North invited members of the Dene Nation* to write much of the material in the anti-fur-harvesting issue which came out in the winter of 1985 . The summer issue of 1986 dealt with native languages, and was constructed around a report generated by a task-force that is busily studying the future of native languages in the NWT.

\footnotetext{
* Consisting of native inhabitants of northern Canada speaking any of the Dene languages (Loucheux, North Slavey, South Slavey, Dogrib, and Chipewyan).
}

The next issue of Information North will deal with militarization of the North and will comprise a number of short essays written from a variety of points of view, both Canadian and international. The issue following that will deal with arts and culture in the North, while subsequent topics will include employment and communications in the North. On some occasions, extra copies of the newsletter are printed and made available for wider distribution in northern regions.

Arctic is the academic journal of the venerable Arctic Institute of North America, now of the University of Calgary. It is currently in its 39 th volume and just recently adopted a more contemporary look, with cosmetic upgrading. Moreover the academic quality and central focus is shifting to include more contributions in the field of social studies, though history, anthropology, and archaeology, remain as mainstays along with physical and life sciences and engineering. Meanwhile politics and economics as well as social planning are becoming increasingly important in the North, and these are giving rise to more submissions on those topics.

Attention is being given to the potential of electronic management in journal and newsletter publishing. So also, in the broader field of information distribution, consideration is being given to the possibility of establishing electronic bulletin boards, and electronic mailing and teleconferencing for northern communities.

\section{GORDON HODGSON Arctic Institute of North America University of Calgary 2500 University Drive $N W$ Calgary Alberta $T 2 N$ IN4 Canada.}

\section{The Council of Europe and Environmental Protection}

Following his election as President of the Parliamentary Assembly of the Council of Europe, Louis Jung, of France, declared that the role of the Council of Europe in environmental protection was vitally important: 'The tasks of conserving our natural heritage and bequeathing a hospitable environment to future generations are of fundamental concern to us as we stand on the threshold of the 21 st century. Environmental problems should be regulated at European level, with the close cooperation of local and regional authorities and the populations of the various different countries.'
The newly-elected President went on to say that 'The Council of Europe is a driving-force proposing specific effective remedies - such as multilateral treaties, recommendations, and publicity campaigns - which are instruments for encouraging and promoting environmental protection in Europe. The Parliamentary Assembly plays a specific role in this field, helping to forge a common awareness throughout Europe, and to establish a network of close cooperation - not merely between member states, but also with Eastern bloc and African countries for instance. If we defend the environment, we are defending the human race and the lives of Europeans.'

\section{Successful Cloning of Flotation Gene with Possible Applications}

A French-American team has identified and cloned a 'flotation gene' that they believe could confer buoyancy on microbes or cellular organisms which normally sink in liquid culture media. They believe that inserting this gene into industrially useful microbes or cellular organisms could improve product-yields by increasing aeration, reducing stirring-needs, and improving organism survival.*

* and, we would think, quite likely having ultimate environmental implications-hence our interest in publishing this note.Ed.
The flotation gene was found and cloned by a team which included Dr Donald Bryant, assistant professor of Molecular and Cell Biology at Pennsylvania State University, and three molecular biologists from the Pasteur Institute in Paris, France. The French scientists are Nicole Tandeau de Marsac, Didier Mazel, and Jean Houmard.

The Penn State-Pasteur Institute team is continuing its collaboration under grants from the US National Science Foundation and the French National Centre for Scientific Research. The idea and method for cloning the flotation gene were patented recently in France by the Pasteur Insti- 